\title{
JUST PRICES
}

\author{
Robert C. Hockett and Roy Kreitner
}

\begin{abstract}
In what sense do market prices represent or convey value? At first glance, such prices might look like the upshot of spontaneous social aggregation without exogenously imposed order: uncoordinated individual trading decisions yield "price information" that is said both to induce socially efficient productive decisions and to set a framework that facilitates coherent and welfare-enhancing consumer choice. But while some trading decisions might well be uncoordinated, far from all of them are; and the rules within which trade is conducted are in any event the product of social choice. When we recognize that these rules of trade and certain public practices of trade affect the terms of trade, we cannot but ask whether the rules, the relevant practices, and the prices they partly produce can underwrite just social arrangements. The shorthand rendition of this question is when are market prices just? In this paper we set out to untangle some of the economic and philosophic issues implicated by this loaded question, and to propose a set of considerations that can aid evaluation of the justice (or otherwise) of market prices.
\end{abstract}

\section{INTRODUCTION}

It is distinctly unfashionable to talk of just prices. The very term seems to betray a lack of sophistication, an appeal to a fruitless query abandoned ages ago. Nonetheless, we believe there is significant insight to be gleaned by reawakening the question of the relationship between justice and market prices. The reason for this is that "the price system" is a crucial part of the infrastructure of our social relations, while relative prices themselves are reflective of those relations. The entire gamut of market transactions is undergirded by the system of prices, ranging from the least significant purchases of trifles all the way through financial deals routinely measured in the millions and billions of currency units. The system enjoys the veneer of purely voluntary interaction, pursued with no organizing intelligence. Phenomenologically, we often gaze upon prices as upon brute facts. Set in distant, disorganized, and seemingly unfathomable processes of aggregation, they appear to inhere in market goods, products, services, or financial assets the way weight inheres in a stone, or smoothness in a pebble. Ultimately, however, the price system is an immense engineering project. As much as it shapes our action by marking relative values, it is shaped by our action in promulgating and 
administering the rules of its operation. And because its operations both reflect and determine so many of the relationships that course through the modern economy, its humanly created rules should bear the scrutiny of sustained reflection.

At the outset, we should probably clear aside one potential misunderstanding that would cloud the inquiry we intend to pursue. In pursuing the question of just prices, we have no intention of raising any claims related to the putatively intrinsic worth of particular goods or classes of goods. There will be no attempt to determine the ideal relationship, say, of the price of a good and the cost of its production, or of the intrinsic value of a particular type of labor. Instead, we will be interested primarily in the structural features of any established system of prices. We will show that while the system may have certain consistent features, it actually works in different ways in different settings. That plurality will be one of the keys to generating a better account of the possible interactions between justice and prices.

The essay proceeds in four steps. Part I specifies a few leading economic and philosophic arguments regarding the relationship between prices and justice that have been offered since the marginalist revolution in economics. Those arguments begin with a confident claim that prices under competition represent a just distribution of the rewards of production and a fullbodied retort to charges that labor is exploited under conditions of capitalist enterprise. Through the twentieth century and into our own day, those claims have beat a nuanced retreat. However, they maintain a rhetorical framework in which market prices typically converge with just relations, while pathologies are viewed as exceptional.

Part II challenges the most attractive version of this line of argument. It proceeds by pointing out three qualitatively different problems with the ideal associated with market prices: first, the fact that prices should not be conceived as arising spontaneously; second, that background conditions often beget prices that undercut the goal of the price system narrowly conceived, which rests on individual choice; and third, that market prices (especially in systemically important areas such as financial assets) are often beset by collective action problems - some familiar, others not - that undermine and in some cases foreclose the system's ability to achieve its allocative goals.

Part III develops some general insights regarding the question of how establishing and administering a price system can answer to considerations of justice. It generalizes the critique 
of spontaneity, making clear that the rhetorical frame implied by the standard account should be upended, indeed reversed. In other words, the quietist attitude toward prices actually existing in most markets should be abandoned in favor of a critical cast of mind, attentive to the fact that most prices are already engineered. It then begins to develop the vocabulary for a line of thinking and associated vision that would take responsibility for prices as we make them. Part IV takes the general insights to specific contexts where the advantages of a more forthright acknowledgment of responsibility for prices is especially promising.

\section{Part I: The Intellectual Background, or the CASE for Prices}

We begin our account of the intellectual background for our argument at the close of the nineteenth century, with the advent of marginalist economics. ${ }^{1}$ Against the backdrop of claims (both from within the scientific community and, more trenchantly, from reformers and popular writers) that labor is systematically exploited in capitalist economies, the leading marginalist economist in the United States formulated a confident answer.

In The Distribution of Wealth, ${ }^{2}$ John Bates Clark met such claims head on, asserting that competitive markets yielded the agents of production their fair shares of the gains generated by production. Clark held that a natural law divided the income of society into wages, which are the earnings of labor; interest, the earnings of capital; and profits, the earnings of the entrepreneur (or coordinator of efficient relations among the agents of production). Despite minor variances traceable to local strengths and weaknesses in bargaining, transactions would converge around market rates governed by a natural law. Crucially, "where natural laws have their way, the share of income that attaches to any productive function is gauged by the actual product of it. In other words, free competition tends to give to labor what labor creates, to capitalists what capital creates, and to entrepreneurs what the coordinating function creates." ${ }^{3}$

\footnotetext{
${ }^{1}$ The doctrine of just price has a much longer pedigree, of course. We forgo discussion of it here because neither the Aristotelian roots, the development by Aquinas, nor the ensuing discussions of the doctrine speak to the general question of the nature of the price system - they are all concerned with just price in a particular transaction, against a particular background.

2 John Bates Clark, The Distribution of Wealth: A Theory of WAgeS, INTEREST ANd Profits (1899). Clark had been publishing the ideas encapsulated in the book as early as 1881 . On Clark's status as "the master of American marginalism," see JOSEPH A. SCHUMPETER, HISTORY OF ECONOMIC ANALYSIS 868-70 (1954).

${ }^{3}$ CLARK, supra note 2 , at 3 (italics in original).
} 
Clark's analysis was based on the idea that the contribution of each function to production was distinguishable, and the further claim that the reward corresponded precisely to the contribution. The background ideal of justice that undergirds Clark's analysis is "to each what he creates," and the book is devoted to proving that the principle in fact accords with the workings of competitive markets. Clark was clear and insistent that the analysis was meant as a refutation of the charge that a competitive labor market leads to exploitation:

The indictment that hangs over society is that of "exploiting labor." "Workmen" it is said, "are regularly robbed of what they produce. This is done within the forms of law, and by the natural working of competition." If this charge were proved, every rightminded man should become a socialist; and his zeal in transforming the industrial system would then measure and express his sense of justice. ${ }^{4}$

Happily for Clark, the upshot of his analysis would be that the charge is false. Wages, interest, and profits are in fact "fixed according to a sound principle, [and] the different classes of men who combine their forces in industry have no grievances against each other. ${ }^{5}$ Clark admitted that "friction" could distort the proper apportionment between wages and profit, but his theoretical conclusion remained that "wages tend to equal the product of marginal labor." Competition guarantees that each agent receives precisely that share of increased wealth he has contributed to the total product, "that is, the amount that the marginal workers produce."

Clark's argument might seem compelling at first blush. Surely factor prices reached under competitive conditions are traceable in some sense to comparative social valuations, and hence are well "on the way" to social justice, as it were, if not yet quite just. In anticipation of our arguments below, however, we should note a crucial "missing person" in connection with Clark's catalogue of factors of production - a person who bears critically upon that "under competitive conditions" qualifier. We mean the rentier.

People passingly familiar with the tripartite division of productive factors found in early treatises on political economy - land, labor, and capital - might, if insufficiently attentive, suppose that Clark is reproducing that taxonomy. In fact, however, Clark has dropped land

\footnotetext{
${ }^{4} / d$. at 4 .

${ }^{5} / d$. at 7-8. The quoted passage is couched in a question that opens the investigation, but its proof is Clark's stated goal, and his conclusion is that the natural law exists and is effective, though subject to frictions that may lead to local distortions.

${ }^{6}$ Id. at 106-07.
} 
altogether from account, and has subdivided the earlier category of "capital" into separate funding and organizing roles assumed, it seems, to be accessible to all. This is crucial for our purposes because, if central elements of a society's productive capacity including land and lendable funds ${ }^{7}$ are held monopolistically or oligopolistically, then not-yet-justified disparities in price-making power among market participants will not be mere "bugs" or anomalies in existing price systems; they will be "features," fully as inherent to those systems as the property arrangements that they presuppose. And this will undermine not only the equating of "marginal product" to "just deserts," but even the coherence of any putatively distribution-independent notion of "product" itself. ${ }^{8}$

Intriguingly, some marginalists noticed what Clark overlooked. One of the founders both of the marginalist tradition and of the linking of marginalism to justice inquiry in particular, Léon Walras, was a committed social reformer and follower of Henry George, among other "redistributionists" - including his father, Auguste Walras. ${ }^{9}$ He was explicit that no system of prices reached under conditions of monopoly or oligopoly could be just, and consistently inveighed against fellow economists for ignoring that fact. ${ }^{10}$ This is why he argued throughout

\footnotetext{
${ }^{7}$ Not to mention, arguably, certain forms of entrepreneurial know-how.

${ }^{8}$ We allude here to the notorious "Cambridge Capital Controversies" of the 1960s, which Paul Samuelson famously conceded to have been "won" by the English, as distinguished from the American (Massachussetts), Cambridge economists. The "English" Cambridgians showed, in essence, that there is no coherent conception of "social product," to which "productive factors" might marginally contribute and hence in relation to which those factors' appropriate rewards might be determined, that is independent of the antecedent distribution of factor endowments themselves - endowments protected and vindicated, or course, by property and contract law.

The dispute prefigures, on an adjacent terrain, that which subsequently broke out between Richard Posner on the one hand, Jules Coleman and Ronald Dworkin on the other hand, over whether KaldorHicksian "efficiency" could serve as a normative yardstick in deciding upon a socially optimal distribution of entitlements. Intriguingly, here too the "U.S." side in the dispute - in this case, Posner - ultimately conceded that it had got things wrong, and on grounds not unlike those that had proved the "American Cambridgians"' undoing earlier: the "wealth" in relation to which optimal distribution was to be evaluated was, like the "product" at issue in the "Cambridge Controversies," itself always the product of antecedent distribution.

For a thorough overview of the "Cambridge Capital Controversies," see G.C. HARCOURT, SOME CAMBRIDGE CONTROVERSIES IN THE THEORY OF CAPITAL (1972). For similar treatment of the Coleman/Dworkin/Posner dispute of the 1980s, see Robert Hockett, The Libertarian Welfare State, 56 CHALLENGE 100 (2013); also Hockett, sources cited infra, notes 19 and 26.

${ }^{9}$ See, e.g., LÉON WALRAS, ÉtUdes d'ÉCONOMIE SOCIALE; THÉORIE de LA RÉPARTITION DE LA RICHESSE SOCIALE 25-30 (1896) (“ÉTUDES"); also LÉON WALRAS, L'ÉCONOMIE POLITIQUE ET LA JUSTICE (1860). A compendium of Auguste Walras' views can be found in AUGUSTE WALRAS, THEORIE DE LA RICHESSE SOCIALE (1849).

${ }^{10}$ See, e.d., WALRAS, ÉTUDES, id., at 42-49.
} 
his days that states should both nationalize land rents - if not land and other natural resources themselves - and put in place legal regimes facilitating the formation of labor and credit cooperatives. ${ }^{11}$ Only this way, he argued, can monopoly rents on land and capital, and monopsony rents on employment, be neutralized, and a just spread of price-making opportunity over a population be realized. ${ }^{12}$ Such reforms also offered means of enabling laborers themselves to become, in Walras' words, capitalists - people who could "borrow from themselves" rather than from others and thereby avoid being effectively "enslaved." ${ }^{13}$ We'll return to this more egalitarian marginalist "road not taken" below.

Marginalism, of course, has remained the backbone of modern economics, and thus many of Clark's insights have held up over the years. His sweeping endorsement of the justice of existing distributions of the proceeds of production, however, did not fare as well. Bracketing, for now, frontal critiques of the kind just referenced in connection with Walras, it is noteworthy that most modern champions of market economies beat a nuanced but strategic retreat on the question of just prices.

Perhaps the most insistent voice on the issue belonged to Friedrich Hayek. Hayek believed that the market order was better than any other system for organizing society. At the same time, he adamantly claimed that it was simply a category mistake to attempt to assess the justice or injustice of a market order. To the question of whether the concept of social justice has any content, Hayek answered with a firm no. He claimed that in "a system in which each is allowed to use his own knowledge for his own purposes, the concept of 'social justice' is necessarily empty and meaningless, because in it nobody's will can determine the relative incomes of the different people, or prevent that they be partly dependent on accident."14

\footnotetext{
${ }^{11}$ Id., at 144-46, 267. See also Léon Walras, Theorie Mathematique du Prix des Terres, in LÉON WALRAS, THÉORIE MATHÉMATIQUe DE LA RICHESSE SOCIALE (1883); and LÉON WALRAS, LeS ASSOCIATIONS POPULAIRES DE Consommation, de Production et de CRÉdit (1865) (“LeS Associations Populaires"). The socialization of land and natural resources is among the earliest and most consistently advocated of Walras's policy proposals throughout his life. See also, e.g., LÉON WALRAS, THÉORIE CRITIQUE DE L'IMPÔT (1861); and LÉON WALRAS, DE L'IMPÔT DANS LE CANTON DE VAUD (1861).

12 WALRAS, LES ASSOCIATIONS POPULAIRES, id., at 20.

${ }^{13} \mathrm{Id}$. at 61. Also WALRAS, ÉTUDES, supra note 8, at 144-45.

${ }^{14} 2$ F.A. HAYEK, LAW, LEGISLATION AND LIBERTY: THE MIRAGE OF SOCIAL JUSTICE 69 (1982).
} 
So, where Clark's claim was that the distribution of income in a market order was just, Hayek's is that it cannot be just or unjust:

We are of course not wrong in perceiving that the effects of the processes of a free society on the fates of the different individuals are not distributed according to some recognizable principle of justice. Where we go wrong is in concluding from this that they are unjust and that somebody is to be blamed for this. In a free society in which the position of the different individuals and groups is not the result of anybody's design - or could, within such a society, be altered in accordance with a generally applicable principle the differences in reward simply cannot meaningfully be described as just or unjust. ${ }^{15}$

Thus, while Hayek believed that remuneration would tend to bring about a correspondence between the remuneration for a service and the value of the service to those who receive them, he acknowledged that "these values which their services will have to their fellows will often have no relations to their individual merits or needs. ${ }^{16}$ Hayek recognized but lamented the fact that popular defenses of market systems relied, unjustifiably, on the "ground that it regularly rewards the deserving, and it bodes ill for the future of the market order that this seems to have become the only defence [sic] of it which is understood by the general public." ${ }^{17}$ For Hayek, the defense of the market order rests not on the justice of the resulting distribution, but rather on the system's capacity to improve welfare:

[W]e use an impersonal process to determine the allocation of benefits precisely because through its operation we can bring about a structure of relative prices and remunerations that will determine a size and composition of the total output which

${ }^{15} / d$. at 69-70. The passage continues by explaining the requirements for justice:

[J] ustice is an attribute of human conduct... Justice requires that in the 'treatment' of another person or persons, i.e. in the intentional actions affecting the well-being of other persons, certain uniform rules of conduct be observed. It clearly has no application to the manner in which the impersonal process of the market allocates command over goods and services to particular people: this can be neither just nor unjust, because the results are not intended or foreseen, and depend on a multitude of circumstances not known in their totality to anybody. Notably missing from this rough-and-ready account of justice is any distinction between human conduct that is pursued individually for personal benefit on the one hand, and collectively for public benefit on the other. Likewise missing is any sensitivity, where intentions are concerned, to the distinction between "intended" and "tolerated" results, or any defense of the suggestion that no unjust upshots of defective arrangements can be "foreseen."

${ }^{16} / d$. at 72.

${ }^{17}$ Id. at 74. 
assures that the real equivalent of each individual's share that accident or skill assigns to him will be as large as we know [how] to make it. ${ }^{18}$

Hayek's defense of markets withdraws from the direct claim of justice, but maintains the general appeal of a market order by reference to a principle of wealth-maximizing allocative efficiency as distinguished from distributive justice. It is noteworthy for purposes of the discussion below that Hayek says nothing about (a) why he assumes that we cannot rectify, collectively, at least some defects in the distribution of what he calls "accidents" that are "not the result of any individual's design" (emphasis added); or (b) why he considers social wealth aggregates deriving from allocative efficiency normatively interesting, given his objection to principled redistribution of such aggregates. ${ }^{19}$ We shall return to this observation in the next Section.

Recently, Daniel Markovits has articulated a theory of market solidarity that brackets the matter of allocative efficiency while reasserting the attractiveness of the price system on a different basis. According to Markovits, market interactions establish prices "as a commensurating frame" through which market actors manage or sidestep value disagreements. ${ }^{20}$ Prices in competitive markets allow for all goods to be measured on a common scale of value (thus the term, "price commensuration"), without anyone's having to merge their competing value systems. Participants in markets not only assign different values to things, they also have different reasons for valuing things in the first place. But markets with money prices allow for a shared frame of value in which no one must agree with or subordinate herself to anyone else where values or reasons for valuations are concerned: "competitive prices arise among traders acting as price-takers. None chooses prices - they just happen, and in the same way, to all traders."21

\footnotetext{
${ }^{18} I d$. at 72 . For Hayek's initial formulation of the idea that the price system generates signals leading to efficient behavior and thus tending toward optimal output, see F.A. Hayek, The Use of Knowledge in Society, 35 AM. ECON. Rev. 519 (1945).

${ }^{19}$ On the ethical indifference of aggregates considered apart from the justice of their distribution, see, e.g., Robert Hockett, The Deep Grammar of Distribution: A Meta-Theory of Justice, 26 CARDOzo L. REV. 3 (2005) ("Deep Grammar"); Robert Hockett, Whose Ownership? Which Society?, 27 CARDozo L. Rev. 1 (2005) (“Whose Ownership?”); Robert Hockett, Putting Distribution First, 18 THEORETICAL INQUIRIES IN LAW 159 (2017) ("Distribution First"). ${ }^{20}$ Daniel Markovits, Market Solidarity (Inaugural Lecture, Guido Calabresi Professorship, Yale University, 2012).

${ }^{21}$ Id. at 10.
} 
Markovits views this (putative) price-making feature of markets as "a moral achievement in its own right," for interrelated reasons, two of which are important here. ${ }^{22}$ First, "the internal normative structure of price commensuration" or the "internal logic" of markets fixes prices according to the decentralized and uncoordinated expressions of preference of every market participant. All participants are price-takers, and thus all are formally equal: "Price commensuration implements an important conception of the formal equality of persons, a conception of equality of status, really." ${ }^{23}$ Second, the price system is a "free-standing value frame" that is shared, public, non-discursive, and foundationless. Participation in the price system, according to Markovits, requires no agreement on base values. People with competing or even warring values can interact on the basis of prices, without having to engage their opposing perspectives.

Furthermore, and crucially for our purposes here, Markovits makes the provocative claim that market contracting based on formal equality, "can authorize arrangements that involve substantive inequality." Thus,

Contracts obligate even where made against unjust backgrounds, including even when (because the party that can do better without the bargain does better within it) they allow one side to leverage underserved bargaining advantages in a way that entrenches injustice. Contract obligation does not depend on setting the world right before contracts are made or require improving the world through contracting. Contract possesses the power to launder injustice, creating legitimate entitlements between parties where previously none existed. ${ }^{24}$

Markovits's argument thus seems more ambitious than one based on allocation. Price commensuration is the creation of a frame of interaction where value is at once shared, public, objectively identifiable, and at the same time bracketed in respect of its content. Prices are settled without discussion, and within the price system people are free to pursue any ends they

\footnotetext{
${ }^{22}$ Markovits spends a brief paragraph on the efficiency of competitive equilibrium pricing as one reason to support them. We won't elaborate on that paragraph here.

${ }^{23} \mathrm{Id}$. at 11 . Markovits goes on to distinguish this type of equality from substantive equality, which is not secured by markets. "The failure of substantive equality does not undo the price-commensuration's formal equality, however, or undermine its moral value." That is of course true enough, but we feel some reticence about celebrating our long-since-established formal equality while our substantive inequality is (a) what has exercised social critics most over the past two centuries and (b) is now steadily worsening. The point is not lost on Markovits, who treats the subject innovatively and in depth in DANIEL MARKOVITS, SNOWBALL INEQUALITY: MERITOCRACY AND THE CRISIS OF CAPITALISM (forthcoming 2018).

${ }^{24}$ Id. at 19.
} 
can imagine for any reasons, without having to convince one another of the desirability or even the legitimacy of those ends. The formal equality and associated "horizontal solidarity" entailed by such a system acts as an independent recommendation for its adoption, and as an argument for a wide scope for freedom of contract. ${ }^{25}$

Once more in anticipation of our discussion below, it bears noting here both what Markovits prescinds from and what he takes for granted. The observation that, at least under certain carefully specified conditions, a system of prices can operate both as a mode of commensuration that renders liberal justice practicable and as a plausible measure of ethically interesting comparative social valuations of disparate goods and services is not itself new. One of us has made this point repeatedly, in these very terms, over the past 15 years - both in addressing what Richard Arneson long ago identified as an "index problem" afflicting certain liberal accounts of justice, and in elaborating an ethically plausible ideal against which to evaluate the successes and failures of our efforts at market-improving legal and institutional optimization over time. ${ }^{26}$

What is distinctive in Markovits' discussion is the suggestion, for seemingly the first time since the $19^{\text {th }}$ century, that the formal equality implicit in the institution of contract and its price-generating properties can serve actually to "launder," rather than simply disguise or obscure, substantive injustice - and that therefore, by implication, the formal "freedom" entailed by "freedom of contract" affords us something to celebrate even in a world in which most actual contracting is substantively and not-yet-justifiedly coercive. What the account prescinds from is precisely those substantive matters, which have constituted the main line of

\footnotetext{
${ }^{25} / d$. at $12-13$. In explaining why market societies trade and price housing, medical care, education, Markovits continues: "This is...a self-conscious commitment, commonly expressed through the familiar ideal of freedom of contract. That ideal affirms the broad scope of markets as a matter of principle, often grounded in anti-paternalist ideas about individual sovereignty that are close cousins to the conception of formal equality of status at the root price-commensuration."

${ }^{26}$ See Hockett, Deep Grammar, supra, note 19 at 1221-33; Hockett, Whose Ownership?, supra, note 19, at 42-48; and Hockett, Distribution First, supra, note 19, 211-20. Also Robert Hockett \& Mathias Risse, Primary Goods Revisited at 34-48 (working paper, 2003), available at https://papers.ssrn.com/sol3/papers.cfm?abstract id=931048; and Robert Hockett, Three (Potential) Pillars of Transnational Economic Justice, 36 METAPHILOSOPHY 93, 95-105 (2005). Arneson's discussion of "the index problem" is in Richard Arneson, Primary Goods Reconsidered, 24 Noûs 429 (1990).
} 
market critiques for at least two centuries. ${ }^{27}$ What the account takes for granted, for its part, is a world in which market participants - even labor and capital market participants - "act as pricetakers," and that prices accordingly "just happen" in those markets. These assumptions are heroic in a world of rentiers such as that in which Walras saw us to be living. ${ }^{28}$ They are yet more heroic in such a world that is transparently of our own making and potential improving, as we discuss more fully below.

There are of course additional modern accounts of the relationship between justice and prices. These three have been chosen because they represent sophisticated yet uncompromising accounts, providing analytical clarity. ${ }^{29}$ Their differences are significant, but their similarities should not be ignored. Two features are especially important for our purposes.

First, for each of these theories, the key feature that lends the price system its normative attraction is its status as the decentralized and unorganized result of competitive transactional behavior. Prices act as informational signals according to which individuals make decisions that require no prior centralized coordination. The charm of the price system is that everyone confronts it in formally equal terms, where no individual directly coerces anyone else. The system is unplanned, and thus requires no collective decisionmaking. The difficulties attendant upon group agreement regarding which resources or services are how valuable - the inherently divisive processes of politics - are imagined as external to the price system.

\footnotetext{
${ }^{27}$ See, e.g., works of the elder and younger Walras cited supra, notes 9-12. There is some irony, in this connection, to be found in the fact that the word "launder" when used in connection with money generally suggests something is being deliberately hidden.

${ }^{28}$ See again works of Walras cited supra, notes 9-12. Markovits acknowledges that "the monopolist stands in a qualitatively distinct relation to the price system." Markovits, supra note 20, at 12 (italics removed). "But the difference between the relations to prices of the rich and the poor is not qualitative but merely quantitative and hence does not undermine price-commensuration or market-solidarity." Id. It is not clear to us what work the putative contrast between "qualitative" and "quantitative" distinctions is doing in this passage; nor, relatedly, is it clear why vast disparities in the price-influencing powers of the rich and the poor would "not undermine price-commensuration or market-solidarity." The very wealthy enjoy much greater price-determining powers than do the very poor, which powers simply reach their limiting points in the cases of monopoly or monopsony. When one reflects further that the very poor historically have been very poor precisely because the very rich have been rentiers with legally sanctioned monopoly or oligopoly power over land and capital, and corresponding monopsony or oligopsony power over labor markets, the attempt to place the rich/poor relation on a qualitatively different (and more solidarityconsistent) footing than that of the monopolist/nonmonopolist relation looks more mysterious still. ${ }^{29}$ For an example of a sophisticated but compromising (or fusionist) account, still highly favorable toward the justice of market pricing, see JOHN TOMASI, FREE MARKET FAIRNESS (2012).
} 
Second, each of these theories relies on a rhetorical frame that treats competitive, decentralized markets as the norm. Departures from competition are acknowledged, and all three theories see such departures as potential obstacles to achieving the attractive qualities of markets. Each of them admits that actual markets are not perfectly competitive, but each builds on the assumption that existing markets approximate competitive conditions, and that departures can be treated as anomalous.

\section{PART II: THE PARTIALITY OF PRICES}

Many of the advantages of (at least some renditions of) the price system and its attendant market ordering are well understood and real. But the conditions under which those advantages pertain are far from general, while departures from those conditions are anything but idiosyncratic. In this part, we outline three kinds of challenge that confront defenses of the price system. We begin by discussing the extent to which prices arise free from collective determinations of value. We then move on to note difficulties that arise from the background conditions under which people enter markets, and in particular the problems that arise when severe departures from endowment neutrality are built in to certain markets. Finally we discuss certain endogenous market dynamics that distort pricing in structurally important cases.

\section{a. Prices and Collective Decisionmaking}

Defenses of the price system rely heavily both on an ideal of decentralization and on an associated form of equality among market participants, according to which values are not decided upon through exercises of either market power or collective deliberation, but rather arise as the products of endless series of unrelated instances of exchange among equals. In Markovits's phrasing, "competitive prices arise among traders acting as price-takers. None chooses prices - they just happen, and in the same way, to all traders." ${ }^{30}$ And this is precisely the ideal that grounds Hayek's vision of a spontaneous order. ${ }^{31}$ The most fundamental problem with this ideal is that it does not hold water even analytically, let alone empirically. True, market prices appear to arise spontaneously from exchanges in antecedently given markets, but the background rules that determine the shape of exchange are anything but spontaneous. Prices do not "just happen" in a completely decentralized and uncoordinated manner. Markets have to

\footnotetext{
${ }^{30}$ Markovits, supra note 20, at 10 . See also Hayek, supra note 18 , at 525-27.

31 F.A. HAYEK, LAW, LEGISLATION AND LIBERTY: RULES AND ORDER 35-54 (1982); HAYEK, supra note 14, at 107-20.
} 
be made, infrastructures supplied, units of account determined and managed, rules established as to what counts as property and what kinds of property are alienable, saleable, and taxable. The rules of property and contract law themselves shape both the contours and the values of entitlements.

Market creation and market maintenance are the products not of spontaneous genesis, but of institutional design, legislative action, and judicial decision. Even more importantly, they do not set an immutable baseline leaving disorganized parties to play a game of price with eternally fixed rules. ${ }^{32}$ Instead, collective, organizational decisions play a central role in manufacturing and moving prices. ${ }^{33}$ Examples of the impact of public decisions on the price system range from the obvious to the more subtle, but most are straightforward enough to mention here without detailed elaboration. On the obvious side, public employment and procurement effectively benchmark prices for some of the most important goods and services in the putatively privately ordered economy. ${ }^{34}$ Similarly, changing background rules make all the difference in pricing many of the most important market interactions. It is hard to imagine pricing pharmaceuticals without patent law; impossible to make sense of real estate prices without local zoning ordinances; incoherent to consider the price of medical care without insurance law. ${ }^{35}$

Less obviously yet more pervasively, the price system cannot actually circumvent inherently contestable valuation because money itself is disseminated and managed via centralized decisions that directly affect prices. ${ }^{36}$ Just to note a notorious example from recent years: banking regulation determines the costs of credit in different sectors of the economy and thus

\footnotetext{
${ }^{32}$ For detailed elaboration, see Duncan Kennedy and Frank Michelman, Are Property and Contract Efficient? 8 HOFSTRA L. REV. 711 (1980).

${ }^{33}$ Robert C. Hockett and Saule T. Omarova, "Private" Means to "Public" Ends: Governments as Market Actors, 15 THEORETICAL INQ. L. 53 (2014).

${ }^{34}$ The entire arms industry is "priced" by what government decides to pay; there is no market for armored personnel carriers or missiles outside government procurement. Less obvious but often just as important, salaries for engineers and other professionals will be extremely sensitive to decisions on military spending. The same is true a step down in the pay scale, for example with the "market" for teaching overwhelmingly dominated by government.

${ }^{35}$ The list could go on for a very long time, including energy markets, transportation, and hosts of others.

${ }^{36}$ Christine Desan, The Monetary Structure of Economic Activity, forthcoming in INSIDE MONEY (Christine Desan ed., 2018); Christine Desan, Money as a Legal Institution, in MONEY IN THE WESTERN LEGAL TRADITION 18 (David Fox and Wolfgang Ernst eds., 2016). For a comprehensive tracing of public money-dissemination throughout the entirety of the modern financial system, see Robert C. Hockett \& Saule T. Omarova, The Finance Franchise, 102 CORNELL L. REV. 1143 (2017).
} 
affects prices, but not equally. Asset prices in financial markets are crucially dependent on decisions by central banks regarding what to accept as collateral on loans. ${ }^{37}$ And when central banks - as agents of the public, or the collective - make their decisions, they move both the price of credit and the prices of major financial assets. ${ }^{38}$ The heart of any price system is its unit of account, and public decisions - be they monetary decisions concerning credit and interest or fiscal decisions concerning what and how much to tax as well as on what and how much to spend - are collectively organized determinants of the value of the unit, i.e., the state's money. ${ }^{39}$ In short, the price system is deliberately engineered rather than spontaneously generated.

\section{The Impact of Background (In)Equality}

We have seen that one key to the attraction of a system of market prices is that it can instantiate a species of formal equality, or what Markovits aptly terms equality of [juridical] status. ${ }^{40}$ In celebrating that form of equality, we have noted, Markovits further suggests that the very process of market contracting has the power to "launder injustice." ${ }^{41}$ But while some market situations might legitimately yield this rather thin form of solidarity, it seems that under many realistic conditions the stain of injustice will be too deep to be laundered. There are two faces of this problem worth mentioning. The first has to do with prices, particularly prices for labor, when background conditions leave parties especially vulnerable. The most obviously salient background condition in this case is that in which one party is essentially property-less. "A person who lives at the mercy of others' provision is vulnerable to exploitation and abuse at their hands, and liable to humiliating forms of subjection. Without property, individuals are unable to defend their rights or advance their claims on others in ways that command respectful

\footnotetext{
37 Perry Mehrling, The New lombard Street: How the Fed Became the Dealer of Last Resort (2010).

38 Hockett \& Omarova, supra notes 33 and 36.

${ }^{39}$ The analytical critique is generally applicable, but as we discuss below it has different levels of bite in different market settings. Its effects are particularly visible at moments of sharp legal change (e.g., extending the duration of copyright, or establishing a right to collective bargaining, or recognizing responsibility of manufacturers for products liability, or shifting to quantitative easing). The important point (again, elaborated on below) is that there are many important settings in which collective determinations have salient impacts on prices.

${ }^{40}$ Markovits, supra note 20 , at 11.

${ }^{41}$ Id. at 4, 19.
} 
attention..." ${ }^{42}$ This vulnerability has occupied the attention of concerned observers of market societies from the time of the Greek municipal and Roman republics, at latest, down to the present. ${ }^{43}$

Another way of stating this concern is that at times market contracting is part of a system that entrenches what might be called substantive as distinguished from juridical status, rather than instantiating any ethically salient form of equality. This is likely the situation for much of the contracted labor in the developing world - not to mention, after decades of legally aided erosion of organized labor influence, the developed world once again. But while this situation poses a serious practical problem (perhaps the most serious problem for a conception of global distributive justice), it may not be theoretically daunting on its own. Defenders of market pricing can, and sometimes do, condition the legitimacy (or at least the desirability) of such pricing on collective bargaining rights for labor, on public employer of last resort programs, or on a guaranteed basic minimum for all citizens. ${ }^{44}$ In this sense, most would agree that prices that expose people to exploitation, to a lack of independence, or to serious deterioration in what, following Rawls, we might call "the social bases of self-respect" ${ }^{45}$ are unjust or at least problematic and require redress. The issue raises thorny boundary questions about what kinds

\footnotetext{
42 Elizabeth Anderson, How Should Egalitarians Cope with Market Risks? 9 THEORETICAL INQ. L. 239, 265-66 (2007).

${ }^{43}$ For discussion of the history of, as well as defense of, this set of concerns, see, e.g., Robert Hockett, Whose Ownership?, supra note 19; Robert Hockett, A Jeffersonian Republic by Hamiltonian Means, 79 S. CAL. L. ReV. 45 (2005). For recent book-length engagement with the same concerns, see, e.g., PHILIP PETTIT, just Freedom (2014); Axel Honneth, Freedom's Right: The Social Foundations of Democratic Life (2015); ROBERT HOCKETT, A REPUBLIC OF OWNERS (forthcoming 2018).

${ }^{44}$ On collective bargaining, see the brief discussion of Walras earlier. On the employer of last resort idea, see, e.g., Robert Hockett, Open Labor Market Operations (working paper, 2013) and Hockett \& Omarova, supra note 33; see, earlier and canonically, H.P. Minsky, The Role of Employment Policy, in POVERTY IN AMERICA (M.S. Gordon ed., 1965); L. RANDALL WRAY, UndeRSTANDING MOdERn MONEY (1998); and sources cited infra, note 68. On the basic income idea, Anderson notes that even Hayek advocated providing such minimum guarantee. $I d$. at 258. So, of course, did Milton Friedman through his "negative income tax" proposals of the 1960s. See Milton Friedman, CAPITALISM AND Freedom (1961).

45 John RaWLS, Political Liberalism 178-87; 315-24 (1993). See also Hockett \& Risse, Primary Goods Revisited, supra note 26.
} 
of products or services should enter the market at all, ${ }^{46}$ and equally difficult questions about the proper comparison points for contracting against facially exploitative backgrounds. ${ }^{47}$

The second face of the problem of status and equality presents a deeper conceptual challenge. Where exchange occurs in exploitative or degrading conditions, as mentioned, most market advocates favor at least some form redress. Indeed, many would point to such exchanges as distortions of properly functioning markets. But how far does the contamination of such exchanges run? As observed in note 47, some market advocates might believe that children are better off working on rubber plantations than their next best alternative. But at some point, almost all would agree that under some conditions there are some exchanges that simply cannot be condoned. That is the backdrop for the challenging question: once those offending exchanges have been carried out and their products have entered the stream of commerce, how does the tainted exchange impact on the potential justice of the prices in ensuing markets? To return to the illustrative case, does it undermine the legitimacy of the price of automobile tires produced by Firestone? Does it undermine the legitimacy of the price of Firestone stock ${ }^{48}$ The Firestone case is perhaps extreme, especially as the charge there was not

\footnotetext{
${ }^{46}$ Obvious examples include the sale of bodily organs, where an intuitive argument is that only someone with "no options" would enter such a contract. See generally, MARGARET JANE RADIN, CONTESTED COMMODITIES (1996); Michael J. SANDEL, What MONEy CAN't Buy (2012).

${ }^{47}$ For a somewhat grotesque illustration, consider the case of a suit involving child labor in Liberia, and Judge Posner's expression of what he saw as a difficulty for recognizing a claim:

We also-and this is the biggest objection to this lawsuit-don't know the situation of Liberian children who don't live on the Firestone plantation. Conceivably, because the fathers of the children on the plantation are well paid by Liberian standards, even the children who help their fathers with the work are, on balance, better off than the average Liberian child, and would be worse off if their fathers, unable to fill their daily quotas, lost their jobs or had to pay adult helpers, thus reducing the family's income. There is a tradeoff between family income and child labor; children are helped by the former and hurt by the latter; we don't know the net effect on their welfare of working on the plantation.

Flomo v. Firestone Nat. Rubber 643 F.3d 1013, 1024 ( $7^{\text {th }}$ Cir. 2011). This seems to imagine that the question of comparative welfare (i.e., with the market contract against the background conditions, or without the contract against the same background) is decisive. While this may be a plausible way to pursue an 'all things considered' distributive justice calculus, it seems seriously deficient as a way to think about the justice of a particular employment relationship. Considering the social bases of self-respect would quite obviously lead the analysis in a different direction. For a related point on the distinction between distributive justice and justice of relations, see Hanoch Dagan and Avihay Dorfman, Interpersonal Human Rights and Transnational Private Law (unpublished manuscript, available at https://papers.ssrn.com/sol3/papers.cfm?abstract id=2860275).

${ }^{48}$ For those who are offended by the implication that Firestone is exploitative, all that is necessary is to take an example extreme enough for your own tastes. Did slave labor in the antebellum United States undermine the legitimacy of the price of cotton shirts?
} 
simply an exploitative contract, but a reliance on child labor. But contracts that raise serious questions of degrading the social bases of self-respect are not rare. The fact that people would rather work in sweatshops than remain without employment, particularly in a world long since "enclosed" where productive property ownership is concerned, would seem to afford insufficient reason to rest quiet in the assurance that the work is not degrading. And importantly, such labor contracts are imbricated through the chain of commodities into most consumer markets in the developed world.

The two phases of the problem of background inequality just highlighted are interrelated. If the first phase of the problem (degrading exchanges) were extinguished, the second phase would disappear. But long supply chains in globalized production processes raise the specter that degrading exchange touches, however indirectly, vast swathes of market activity. As a matter of intuition, the farther one is from degrading exchanges themselves, the less urgent might seem any concern over the justice of the price system in which one is buying and selling; the taint will at some point, perceptually speaking, attenuate. But this is akin to believing infections benign because microbes are microscopic. That one does not see the slaves weaving ones clothes does not mean they're not there; nor, by extension, does it means that one's cheap textiles are justly priced. This threat to the integrity of the price system thus remains a significant challenge for its champions whether it is immediately visible or not, especially if they take seriously the idea of the social bases of self-respect.

\section{Recursive Collective Action Problems}

The second challenge to the "naturalist" account of prices just discussed, along with some aspects of the first such challenge, can be viewed as being in a certain sense analytically exogenous to that account even if practically unavoidable. There is, in other words, at least something by way of a "there there" to which proponents might be appealing or for which they might be groping, even if some proponents occasionally manifest a surprising ignorance of or indifference to the extra-systemic prerequisites to the price systems that they idealize. The third challenge we wish to highlight, by contrast, is thoroughly endogenous to the idealized account itself; it undercuts the very idea of a price system as a sort of watch that can tick on indefinitely once the public watchmaker has built it, wound it, and set it in motion. 
The price system as we know it is commonly distorted by vast array of recursive collective action problems. ${ }^{49}$ These are situations in which individually rational actions aggregate into collectively irrational outcomes (the collective action problem simpliciter, itself a canonical "market failure"), as calamitously worsened by agent-interactive, iterative, and accordingly selfexacerbating structures. ${ }^{50}$ The bank run and the asset price "fire sale" are particularly salient examples in the wake of the world's recent financial dramas, but financial markets and macroeconomies more generally are pervasively susceptible to such market-destroying dynamics. Positional goods arms races, asset price bubbles and busts, consumer price hyperinflations and debt-deflations are all poignant cases in point. ${ }^{51}$

One of the more curious, if not indeed ironic, aspects of the phenomenon of recursive collective action problems is its particular grip on what is often portrayed as the very citadel of rational pricing: financial assets. Efficient markets hypotheses of various stripes suggest that financial markets impound all relevant information in prices at any given time. That might be so if we read the qualifier "available" into the phrase "relevant information." ${ }^{52}$ But because financial assets often are traded to be traded - that is, speculatively bought to be sold - there is no natural brake on their price dynamic. That is particularly so when trades are financed by indefinitely extensible, endogenous credit, the limits of extensibility being apparently unknowable and accordingly uncapturable by asset prices even in informationally efficient markets. ${ }^{53}$ Some find this vulnerability nothing short of paradoxical: the markets that come closest to "efficiency" in the sense that trades are nothing but trades, without friction, without natural stickiness, are precisely those markets where self-reinforcing destructive dynamics are most prevalent, and most dangerous. ${ }^{54}$

\footnotetext{
${ }^{49}$ This class of problems is introduced and discussed in Robert Hockett, A Fixer-Upper for Finance, 87 WASH. U. L. ReV. 1213 (2009) and Robert Hockett, Bretton Woods 1.0: A Constructive Retrieval 16 N.Y.U. J. L. \& PUB. Pol'Y 1 (2013). For systematic explication, by reference to a large class of examples, see Robert Hockett, Recursive Collective Action Problems: The Structure of Procyclicality in Financial and Monetary Markets, Macroeconomies, and Formally Similar Contexts, 3 J. FIN. PERSPECTIVES 1 (2015).

50 See Hockett, Recursive Collective Action Problems, id.

${ }^{51} \mathrm{ld}$.

52 See, e.g., Hockett, A Fixer-Upper for Finance, supra note 49 on this point. Also Robert Hockett, Bubbles, Busts, and Blame 37 CORNELL LAW FORUM 14 (2011).

53 Id. Also Hockett, Recursive Collective Action Problems, supra note 49 at 18.

${ }^{54}$ For additional accounts of such dynamics focused more on liquidity than credit, see JOHN MAYNARD KeYNeS, The General TheORY Of EMPLOYMENT, INTEREST, AND Money, Chapter 12 (1936); and, more recently, MORGAN RICKS, THE MONEY PROBLEM 85-101 (2016). For an early account stressing margin-buying and credit,
} 
Curious paradoxes aside, the fact is that the price system is open to severe distortions that allow for no or multiple equilibria and are not self-correcting. ${ }^{55}$ Monetary authorities and other policymakers are in varying degrees aware of this vulnerability and take it seriously, sometimes putting in place structures to avoid or to mitigate its most undesirable effects - particularly when they concern what one of us has elsewhere called "systemically important prices." ${ }^{16}$ Those mechanisms are critical parts - indeed often existentially critical parts - of a collective engagement that makes prices. And when those mechanisms are not in place, the dynamics themselves affect prices - often, again, catastrophically. The bottom line is that the price system's ability to generate coordination is limited when faced with such endogenously generated dynamics; and when those dynamics are corrected, it is the collective work of institution-making that generates prices.

\section{Part III: General Considerations on Price Determination}

The justifications for the price system as the backbone of a just market order embrace generality on two fronts. In principle, such arguments espouse market ordering as the most generally applicable and desirable mode of distribution; in other words, they favor using the market for the widest array of provision possible. ${ }^{57}$ As a matter of rhetoric, as we suggested above, such arguments paint a picture of actual markets as approximating ideal or competitive markets. The desirable features of the markets they favor include competition (meaning both the absence of monopoly and monoposony and the absence of other sources of market power) and crucially, the fact that prices are not determined by anyone in particular. Everyone recognizes that actual markets do not achieve perfect competition, but the departures from the ideal are presented as minor and anomalous, at least for purposes of evaluating the price system.$^{58}$ From our perspective both faces of generality are problematic. As our view of markets

see IRVING FISHER, BOOMS AND DEPRESSIONS (1932); and Irving Fisher, The Debt-Deflation Theory of Great Depressions, 1 ECONOMETRICA 337 (1933).

55 See sources cited supra, note 41.

${ }^{56}$ Robert Hockett \& Saule T. Omarova, Systemically Significant Prices, 2 J. FIN. REG. 1 (2016).

57 See, e.g., Markovits, supra note 20, at 13; TOMASI, supra note 29, at 242-47.

${ }^{58}$ We call this a matter of rhetoric because analytically, most arguments for market ordering are open to many readings. If one were to highlight the known departures from the ideal model, many of these arguments can themselves be turned into the basis of critique of actually existing market societies. But the rhetoric, at least in the most important cases, is certainly not accidental. For an elaboration of the 
becomes more realistic, attentive both to indispensible background conditions and endogenous market-structural characteristics, we see that their heterogeneity is actually a dominant feature.

When we take the heterogeneity of market pricing into account, a set of important insights emerges. First, the price system works differently in different contexts. At some times in some places, it is indeed a decentralized coordination mechanism of the type that Hayek famously described. ${ }^{59}$ But for the most part, that coordination relies quite heavily on centralized decisions that come in many forms: benchmarking, market making, market moving, market levering, and backstopping, among others. ${ }^{60}$ The conventional frame depicts complete decentralization as the norm, with "intervention" as an anomaly or potential "distortion" to be justified, such that any "tampering" with prices should be avoided except where absolutely necessary. But this picture gets things sideways if not backwards. It misconstrues actual markets badly, and it posits as a general ideal a norm that ought to be applied only where it actually serves its goals. In other words, it relies on a grossly distorted descriptive account to generate a poor normative orientation.

The first step toward a better understanding of the price system is the recognition that many prices, including many of the most important prices from a systemic perspective, ${ }^{61}$ are engineered - directly or indirectly - by public institutions. This is perhaps most decisively and most obviously true for interest rates (i.e., the rental price of money, or credit), which are determined and managed by central banks. But those who find the dynamics of interest rates esoteric or obscure should not be fooled into thinking that is the only important price engineered by or through public institutions. Interest rates happen to be an area where governments affect both the background conditions (in taxing and spending decisions) and the foreground conditions (by determining short term interest rates such as the Fed Funds Rate

argument that "the advantages of competition do not depend on it being perfect," see 3 F.A. HAYEK, LAW, Legislation and Liberty: The Political Order of A Free People 65-67 (1982).

${ }^{59}$ Hayek, supra note 18. For an elaboration that emphasizes the important distinction between coordination and incentives, see John E. Roemer, Prospects for Achieving Equality in Market Economies, in THE OXFORD HANDBOOK OF ECONOMIC INEQUALITY 693, 697-99 (Wiemer Salverda et al. eds., 2009). 60 Some of this taxonomy is developed in Hockett \& Omarova, supra note 33; and elaborated further in both Hockett \& Omarova, supra note 56 and Robert C. Hockett \& Saule T. Omarova, Public Actors in Private Markets: Toward a Developmental Finance State, 93 WASH. U. L. REV. 103 (2015).

${ }^{61}$ For an account of which prices are systemically significant, how prices or indexes take on such status, and what sorts of policy response their significance underwrites, see Hockett \& Omarova, Systemically Significant Prices, supra note 56. 
through open market operations). Crucially, however, entire sectors of the economy including education, energy, and health care are dominated by prices with heavy engineering aspects, as are markets in some of the most important commodities. Sometimes the results are perverse; 62 sometimes, markedly beneficial. ${ }^{63}$ The important starting point for serious discussion is that we already generate a vast array of prices through complex interactions of public and private action: spontaneously arising prices with little central coordination do not present a general case - they are far more apt to be the exception than the rule.

The next step is acknowledge that the engineered character of prices gives the lie to the idea that there is no planning. At least where prices are engineered, we require a better vocabulary to consider and evaluate the engineering that occurs, as well as the social relations that it assumes and advances. The supposed abdication of responsibility for pricing is bad enough as a missed opportunity; it is even worse when it masks sub-rosa decisions with regressive implications - and worse still when the arrangements are not simply distributively regressive, but positively destructive.

One additional step would be a classification that points in a normative direction: some aspects of pricing should be pushed toward the ideal forms of market coordination. That is, many of the arenas where prices can be structured such that they approximate something like "democratically regulated endowment-neutral" ${ }^{64}$ market mechanisms are arenas that would be desirable sites of coordination. But even that ideal is not complete. There are cases in which the social relations arising from a transactional world simply do not advance, and can even impede, the ultimate goals of the ideal.

This claim needs unpacking. First, one has to recall that the market ideal, even in its endowment neutral egalitarian form, is not an ultimate end. It is instead an instrumentality whose goal is to assist in instantiating a social structure in which people have the best chance to

\footnotetext{
${ }^{62}$ Consider the interlocking price engineering of sweetener: sugar farmers enjoy a tariff, so the price of sugar is high; corn farmers enjoy a subsidy, so the price of corn syrup is low. The prices lead producers, say of soft drinks, to prefer corn syrup, and health effects of producing with corn syrup rather than sugar are apparently disastrous. LAWRENCE LESSIG, REPUBLIC LOST 44-52 (2012).

${ }^{63}$ Consider the first five decades (at least) of government support for a secondary market in mortgages, which buoyed the construction industry and increased home-ownership by half. See Hockett, $A$ Jeffersonian Republic by Hamiltonian Means, supra note 19 ${ }^{64}$ Hockett and Omarova, "Private" Means to "Public" Ends, supra note 33, at 57. Also Hockett, sources cited supra, note 19.
} 
develop themselves. By linking economic freedom to individual choice and self-development, the market ideal attaches itself to a vision of personal autonomy - this is its key strength. But it is the autonomy or self-government that we are after, not the market for its own sake. So, where market transactional pricing does not advance (or even undermines) self-government, we have to look for other mechanisms of linking people in cooperative relationships. One of the problems with the current ideal (or translation) is its individualism, which has inherent difficulty in tracking the goods that no single individual imagines as a singular opportunity for advancement, but which are clearly benefits to large numbers of groups and individuals.

Some of these areas are places where disaggregated preference expression through prices simply cannot account for socially important goods - public goods are the obvious, but far from the only example. Some are places where the underlying good is part of the social bases of selfrespect (thus, probably, health care). Other areas where planning is necessary seem ripe for this type of work. The challenge is not to allow these areas of planning to become brakes on innovation, which we often associate with the unplanned spontaneity and even the chaos of markets. With these general considerations in mind, we move onto some examples of areas where a more active orientation toward collectively setting or influencing prices will allow the price system to advance plausible conceptions of justice.

\section{PART IV: JUST PRICING IN ACTION}

The price system is less of a spontaneous "marvel" 65 or a force of nature than many of its advocates would have us believe. From our perspective, the upshot of the preceding analysis is double: first, we should be more mindful of the fact that in practice much of the price system is engineered, and thus we should be watchful that existing practices of price engineering are geared toward justifiable goals. Second, the fact that the price system is always a mix of public and private action should give us more confidence in designing normatively attractive modes of pricing. In short, we should be much less squeamish than is typical in pursuing just pricing. The analysis of existing departures of pricing from successful spontaneous order, along with the general considerations outlined above, offer potential guidance for developing examples of

65 The phrase is Hayek's, and he notes its deliberate use to "shock the reader." Hayek, supra note 18, at 527. 
what just pricing might look like in action. In what follows, we first mention a number of discrete potential paths for generating examples and then sketch one integrative example.

One avenue toward developing examples is to target areas where the noted weaknesses of the model of spontaneous pricing (existing collective pricing; background inequality; and recursive collective action problems) are particularly egregious and salient.

Regarding existing collective decisions on pricing, consider the prices of pharmaceuticals as currently governed by the patent system. The patent system allows firms that develop popular drugs to enjoy monopoly pricing, pricing many potential users out of the market. A prize system, on the other hand, reduces prices (to close to cost) and radically increases access to medicine, but retains the advantages of competition regarding potential lines of research and innovation. ${ }^{66}$ This is simply the choice of one system of coordination over another: a prize system represents no more intervention than a patent system. But its effect on prices is completely different, and holds the promise of mitigating or eliminating several of the most insidious features of the patent system. ${ }^{67}$

On the issue of background inequality, it is clear that conditions of extreme poverty are breeding grounds for transactions that can impinge on the social bases of self-respect. It is similarly clear that the correlation between extreme poverty and unemployment or underemployment is high. Currently, welfare support, such as it is, in combination with the minimum wage, serves as something of a floor on these conditions. A universal basic income or "negative income tax," noted above, might operate similarly. A more ambitious remedy, also noted above, would be a public "employer of last resort" function of the kind first proposed by Minsky, subsequently advocated by Minsky's student Wray, and now advocated by a growing chorus of advocates. ${ }^{68}$ Under such a program, the government offers to employ anyone willing

\footnotetext{
${ }^{66}$ For a detailed analysis, see WILLIAM W. FISHER III AND TALHA SYED, INFECTION: THE HEALTH CRISIS IN THE DeVeloping World And What We Should Do About It ch. 5 (2017); William W. Fisher and Talha Syed, A Prize System as a Partial Solution to the Health Crisis in the Developing World, in INCENTIVES FOR GLOBAL PUBLIC HEALTH 181 (Thomas Pogge ed., 2010).

67 The example is meant to be illustrative, not conclusive regarding pharmaceuticals. The point is simply that there are areas where we use background rules as massive, fairly blunt tools that generate prices and that they are not necessarily the best tools. Where others are available, the basic sensitivity to the fact that existing prices are engineered should be liberating when considering alternatives. ${ }^{68}$ See sources cited supra, note 44; also HYMAN MINSKY, ENDING POVERTY: JOBS, NOT Welfare (2013); Pavlina R. Tcherneva, Beyond Full Employment: The Employer of Last Resort as an Institution for Change, Levy
} 
and able to work, effectively eliminating unemployment. Just as important from our perspective, the wage offered by the employer of last resort would functionally benchmark wages - something that is not true of a minimum wage when unemployment still exists. ${ }^{69}$ The program would not be costless (though savings on current public assistance programs and additional tax revenues generated by employment-induced macroeconomic growth might well outrun costs within a short time, especially once the economy is healthy). But the important point is that in a relatively simple manner, we could, acting collectively through our public instrumentalities, effectively set a wage that would obviate the most routine aspects of degrading life conditions by moving the price of marginal labor.

On the issue of recursive collective action problems little need be said to those familiar with our still-recent financial market troubles. Deposit insurance for commercial banks, combined with regulatory conditionality and the Fed's lender of last resort function, essentially ended the problem of runs on banks in the 1930s following the 1929 crash. During our more recent financial crisis, governments and central banks stepped in as "dealers of last resort" to put a floor on the prices of financial assets being run-on in "fire sales," again accompanying the "bailouts" with later-imposed regulatory conditions. A broader "market-maker of last resort" function could expand both the types of assets eligible and the types of financial or non-financial actors with access to such price determination - provided, again, that regulatory strings were attached to head-off abuse of the safety net. ${ }^{70}$

Finally, consider the following integrative example. Throughout the advanced economies the last forty years have witnessed a major transformation in the mode of savings for retirement. Defined benefit plans are mostly an historical relic; defined contribution plans once seemed to leave a fair amount of decision-making power with the workers affected by the plans (or their unions). Over the last forty years, however, the remnants of such solidarity in investing have dissipated, as fund managers increasingly work precisely according to financial industry standards with the sole goal of maximizing the returns of the fund. ${ }^{71}$ Pension savings have

Economics Inst. Working Paper No. 732 (2012), available at http://www.levyinstitute.org/pubs/wp 732.pdf.

${ }^{69}$ WRAY, supra note 44 , at 128 (arguing that minimum wage laws are effective only at full employment).

${ }^{70}$ Hockett, supra note 49, at 28-32.

${ }^{71}$ Michael A McCarthy, Dismantuing Solidarity: Capitalist Politics and American Pensions since the New Deal (2017). 
become more individualized, and the institutional investors who manage them are the epitome of the search for yields. Some academics might be surprised to learn that even the once hallowed "non-profit" investment company TIAA is now affected by this trend, portending ominous changes to come. ${ }^{72}$ Over the course of nearly half a century, money that was initially held in safe assets (like government bonds, or corporate bonds of the largest companies) has shifted drastically into equities, fueling a huge rise in the market capitalization of US stock markets. This has, in effect, been a system of price supports for the capital markets.

Such a system raises a host of questions. It is far from clear that workers whose pension savings are funneled into the markets will be better off in terms of returns at the time of their retirement. At the very least, such workers have become subject to much greater volatility as their pension savings become more and more speculative. But even if we assume that the bottom line at the moment of retirement is a net gain (again, not a sure bet by any stretch of the imagination, as retirees during 2008-09 will attest), the overall effects of such a major shift are dubious as far as workers are concerned..$^{73}$ The current situation focuses the investment strategy of the funds on a single goal, which is maximizing profits. It ignores two aspects of longterm savings that could be crucial for the savers: first, the importance of stability; and second, the potential impact of the investment in real time.

For illustrative purposes, imagine being given the following choice: 1 . invest in an index of foreign stocks, with your average return being 100 - however with equal chances of it being 75 or $125 ; 2$. invest in a community development project in your own community with an average return of 95 with low volatility (say equal chances of 98 or 92). Now factor in the fact that the work in your own community also promises positive externalities in the community. Perhaps some of those positive externalities are even monetizable. With these numbers, this is obviously an easy case, and not just for the risk averse.

\footnotetext{
72 See Gretchen Morgenson, "The Finger-Pointing at the Finance Firm TIAA," New York Times, October 21, 2017, available at https://www.nytimes.com/2017/10/21/business/the-finger-pointing-at-the-financefirm-tiaa.html?smid=fb-share.

73 The most startling problems arise when a retirement fund makes a strategic investment that directly harms members of the fund, for instance by making possible the outsourcing of their jobs. David $\mathrm{H}$. Webber, The Use and Abuse of Labor's Capital, 89 N.Y.U. L. REV. 2106 (2014).
} 
Setting up the latter possibility requires some serious financial engineering. But it doesn't actually require any more "intervention" into the financial system than the current skew toward long term investment in the capital markets. In order for such projects to be viable, it is likely that the government would have to set up something like a national investment authority (or several such local authorities). Such an authority would engage in "a wide range of financial market activities explicitly aimed at the provision of broadly-defined - and currently undersupplied - public goods." ${ }^{74}$ The authority would run competitive bids for socially beneficial projects. And given the current state of infrastructure in the US, picking winners is a matter of reaching for low hanging fruit.

The details of such a mechanism are far beyond the scope of our inquiry here. ${ }^{75}$ The important thing to note is the relatively long chain of important prices that would be directly affected by such a mechanism. A large set of well-paid (many would say overpaid) middle-men who manage the investments of large scale institutions - the managers in Minsky's money manager capitalism, ${ }^{76}$ would be constricted. The fees that savers pay those managers would for the most part disappear. But most importantly, the costs of socially beneficial projects whose profit stream is either too long-term or too insecure would be drastically cut. Many projects that simply cannot be funded right now would have secure sources of income. The potential positive spillovers of such a project are staggering.

This is not the place to develop a full policy proposal. But the example is telling: it suggests that pricing as we generally conduct it often leaves important societal benefits off the table. When we approach the issue of pricing as an engineering challenge that is endemic to our law and politics, we can reassume responsibility for making society a better place. And that is what thinking about justice and prices should constantly remind us of.

CONCLUSION

\footnotetext{
${ }^{74}$ Robert C. Hockett and Saule T. Omarova, Private Wealth and Public Goods: A Case for a National Investment Authority, 43 J. CORP. LAW__ (33 in draft, at note 153) (2017).

${ }^{75}$ For many of the details on the investment side, see $i d$. On the funding side, the model here is more straightforward, as it taps into pension savings directly, without waiting for decisions by current institutional investors. ${ }^{76}$ L. Randall Wray, Minsky's Money Manager Capitalism and the Global Financial Crisis, 40 INT'L J. POL. ECON. 5 (2011).
} 
We've covered a fair bit of ground here - we hope not too much. In considering the "ethical challenges of the market" as was our brief at the conference for which we prepared this essay, it seems natural to devote some attention to that most central and salient of market upshots, market prices. We have attempted to make a case for the proposition that, just as the distributions of benefits and burdens worked by markets are fit subjects of justice inquiry, so are those distributions' most immediate reflections and determinants - market prices. Insofar as we have succeeded in making the case, it will be clear that market prices can reflect and perpetuate varyingly just and unjust spreads of good and ill over the populations that make use of markets as modes of allocation and distribution. There can in this sense be varying just and unjust prices. To say this does not entangle one in medieval disputation over "just price theory," what ever the range of adjacency between those disputations and our reflections. It simply calls attention to what ought to have been obvious all along - that prices, as what Marx memorably called projections of social relations, will tend to be no more and no less just than those relations themselves. That means our efforts to improve the latter will proceed in tandem with our efforts to improve the former. 